\title{
Increased activity of ionised calcium in gall bladder bile in gall stone disease
}

\author{
M Rudnicki, T Jørgensen, J Thode
}

\begin{abstract}
The actual activity of ionised calcium $\left(\mathrm{Ca}^{2+}\right)$ in gall bladder bile determined with an ion-selective electrode was significantly higher in patients with gall stone disease $(n=15)$ than in patients without gall stones $(\mathrm{n}=10)(0.43 \mathrm{mmo} / \mathrm{kg} v$ $0.31 \mathrm{mmol} / \mathrm{kg} ; \mathrm{p}<0.05)$. No change in the $\mathrm{Ca}^{2+}$ activity in any of the gall bladder bile samples was observed during equilibration with $\mathrm{CO}_{2}$. During titration with $\mathrm{HCl} / \mathrm{NaOH}$, however, the $\mathrm{Ca}^{2+}$ activity fell with increasing $\mathrm{pH}$ in a biphasic manner, with the breaking point occurring at a significantly lower median $\mathrm{pH}$ in patients with gall stones than in patients without (pH 7.1 $v 8.2 ; \mathrm{p}<0.0001$ ). The combination of a higher activity of calcium in bile and precipitation of bile salts taking place at a lower $\mathrm{pH}$ in patients with gall stone disease than in patients without gall stones suggests a major role for calcium and $\mathrm{pH}$ in the pathogenesis of gall stones. Strict anaerobic sampling is not necessary for the measurements of $\mathrm{Ca}^{2+}$ in gall bladder bile, because the $\mathrm{Ca}^{2+}$ was not significantly affected by the changes in $\mathrm{pCO}_{2}$. The metabolic studies suggest, however, that simultaneous measurements of the activity of $\mathrm{Ca}^{2+}$ and $\mathrm{pH}$ is important in order to interpret data for the calcium activity in gall bladder bile.
\end{abstract}

(Gut 1992; 33: 1404-1407)

In the Western world cholesterol is the predominant component of stones in the gall bladder.' Cholesterol gall bladder stones may be initiated by precipitation of calcium salts to form a nidus, with subsequent laying down of cholesterol from its supersaturated state on this nidus. ${ }^{2}{ }^{3}$ Bile salts are important buffers for calcium ion, which may act to reduce free calcium ions $\left(\mathrm{Ca}^{2+}\right)$ in the bile thereby reducing calcium lithogenicity. ${ }^{2}$

Although several studies have focused on bile calcium, specifically the $\mathrm{Ca}^{2+}$ as a major factor involved in gall stone formation, conflicting results have been achieved on the level of $\mathrm{Ca}^{2+}$ in bile. Studies in artificial solution of bile salts or in animal bile report increased concentration of $\mathrm{Ca}^{2+}$ in gall stone formation. ${ }^{4-8}$ In man both increased and decreased concentrations of ionised calcium in bile have been reported. ${ }^{-11}$ All studies convert the measured activity to a concentration, although such a conversion may be inaccurate because of the unknown activity coefficient (variation in ionic strength and effects of bile salts anions).

Gall bladder bile collection is traditionally collected anaerobically, although the effect of aerobic/anaerobic - that is, $\mathrm{CO}_{2}$ loss from the bile sample, sampling techniques on the activity of $\mathrm{Ca}^{2+}$ is unknown.
We present results for the actual activity of $\mathrm{Ca}^{2+}$ and $\mathrm{pH}$ in human gall bladder bile from patients with gall stone disease and in patients without gall stones (controls). We also investigated the relationship between the activity of $\mathrm{Ca}^{2+}$ and $\mathrm{pH}$ in vitro by equilibration with two different $\mathrm{CO}_{2}$ tensions and by titration with $\mathrm{HCl}$ / $\mathrm{NaOH}$.

\section{Methods}

\section{PATIENTS}

Fifteen patients, 12 women and three men (age range 31-57 years) with gall bladder stones were included. Patients with previous cholecystitis diagnosed by scintigraphic examination of the gall bladder were excluded. Ten patients, six women and four men (age range 29-67 years) without gall bladder stones, who underwent cholecystectomy and liver resection comprised the control group. Liver resection was performed for hepatic metastases (eight), cystic echinococcus (one), and hepatic haemangioma (one). All patients had normal serum concentrations of liver enzymes and bilirubin and were included consecutively in the study. Informed written consent was obtained before the study. The study was approved by the local ethical committee.

In patients with gall bladder stones gall bladder bile was aspirated after ligation of ductus cysticus during elective cholecystectomy. In controls the liver was examined before resection by ultrasound in order to assess whether liver resection was possible or there were multiple hepatic metastasis. In 10 patients who were found suitable for biliary/hepatic surgery the ductus cysticus was then ligated and gall bladder bile was aspirated. The latter procedure was in agreement with the recommendations from the local ethical committee.

\section{BIOCHEMICAL ANALYSIS}

Biochemical analysis and titration studies were done without knowledge of the diagnosis.

Whole bile samples were collected anaerobically and into sterile tubes. Measurements of $\mathrm{Ca}^{2+}$ and $\mathrm{pH}$ were carried out immediately after the collection.

The $\mathrm{Ca}^{2+}$ in bile was measured in duplicate at $37^{\circ} \mathrm{C}$ with an ICA 1 analyser (Radiometer, Copenhagen, Denmark), which provides simultaneous measurements for the activity of $\mathrm{Ca}^{2+}$ and $\mathrm{pH}$. The primary calibration solution had a molality of $\mathrm{Ca}^{2+}=1.25 \mathrm{mmol} / \mathrm{kg} ; \mathrm{mCa}^{2+}$; ionic strength, $I=160.0 \mathrm{mmol} / \mathrm{kg}$; molal activity coefficient $0.304^{12}$; activity molality $=\mathrm{mCa}^{2+}$ $(1 \cdot 25 \mathrm{mmol} / \mathrm{l}) \times$ molal activity coefficient $(0 \cdot 304)$ 
Activity of ionised calcium $\left(\mathrm{Ca}^{2+}\right), \mathrm{pH}$, the substance concentrations of sodium $\left(\mathrm{Na}^{+}\right)$, potassium $\left(\mathrm{K}^{+}\right)$, chloride $\left(\mathrm{Cl}^{-}\right)$, albumin and bilirubin in human gall bladder bile from patients with gall stone disease and without

\begin{tabular}{lcc}
\hline & Patients with gall stones $(n=15)$ & Controls $(n=10)$ \\
\hline $\mathrm{Ca}^{2+}$, active molality $(\mathrm{mmol} / \mathrm{kg})$ & $0 \cdot 43(0 \cdot 37-0 \cdot 60)$ & $0 \cdot 31^{\star}(0 \cdot 24-0 \cdot 33)$ \\
$\mathrm{pH}^{+}(\mathrm{mmol} / \mathrm{l})$ & $7 \cdot 50(6 \cdot 78-7 \cdot 80)$ & $7 \cdot 89^{\star}(7 \cdot 68-8 \cdot 20)$ \\
$\mathrm{Na}^{+}(\mathrm{mmol} / \mathrm{l})$ & $159(131-192)$ & $144(104-176)$ \\
$\mathrm{K}^{+}(\mathrm{mm})$ & $6 \cdot 8(3 \cdot 9-12 \cdot 0)$ \\
$\mathrm{Cl}^{-}(\mathrm{mmo} / \mathrm{l})$ & $7 \cdot 5(4 \cdot 8-11 \cdot 5)$ & $69(56-124)$ \\
Albumin $(\mu \mathrm{mol} / \mathrm{l})$ & $54(42-95)$ & $185(140-200)$ \\
Bilirubin $(\mathrm{mmol} / \mathrm{l})$ & $200(138-250)$ & $2000(10-4420)$
\end{tabular}

${ }^{\star} \mathrm{p}<0 \cdot 05$. Results are given as median and $95 \%$ confidence limits.

$=0.380 \mathrm{mmol} / \mathrm{kg} .{ }^{13}$ The relative standard deviation within series $(\mathrm{CVs})$ and between series $(\mathrm{CVd})$ were $0 \cdot 9 \%$ and $1 \cdot 2 \%(\mathrm{n}=22)$, respectively.

IN VITRO $\mathrm{Ca}^{2+}$ EQUILIBRATION

The relationship between $\mathrm{pH}$ and the activity of $\mathrm{Ca}^{2+}$. was studied by equilibrating bile in duplicate for 11 patients with gall stones and nine controls at two different $\mathrm{CO}_{2}$ tensions $(5 \cdot 3 \mathrm{kPa}$ and $10.6 \mathrm{kPa}$ ). $\mathrm{CO}_{2}$ tension was changed by the use of the BMS2 Mk2 Blood Micro System analyser (Radiometer, Copenhagen, Denmark).

TITRATION STUDIES

Titration studies in gall gladder bile were undertaken with $\mathrm{HCl}$ and $\mathrm{NaOH}$ in the same patients as studied by $\mathrm{CO}_{2}$ equilibration. We used $2 \mathrm{ml}$ of each gall bladder bile sample for titration studies. The titration curve was established by stepwise addition of approximately $5 \mu \mathrm{l} 1 \mathrm{molar}$ $\mathrm{HCl}$, or $\mathrm{NAOH}$. Each titration curve comprised

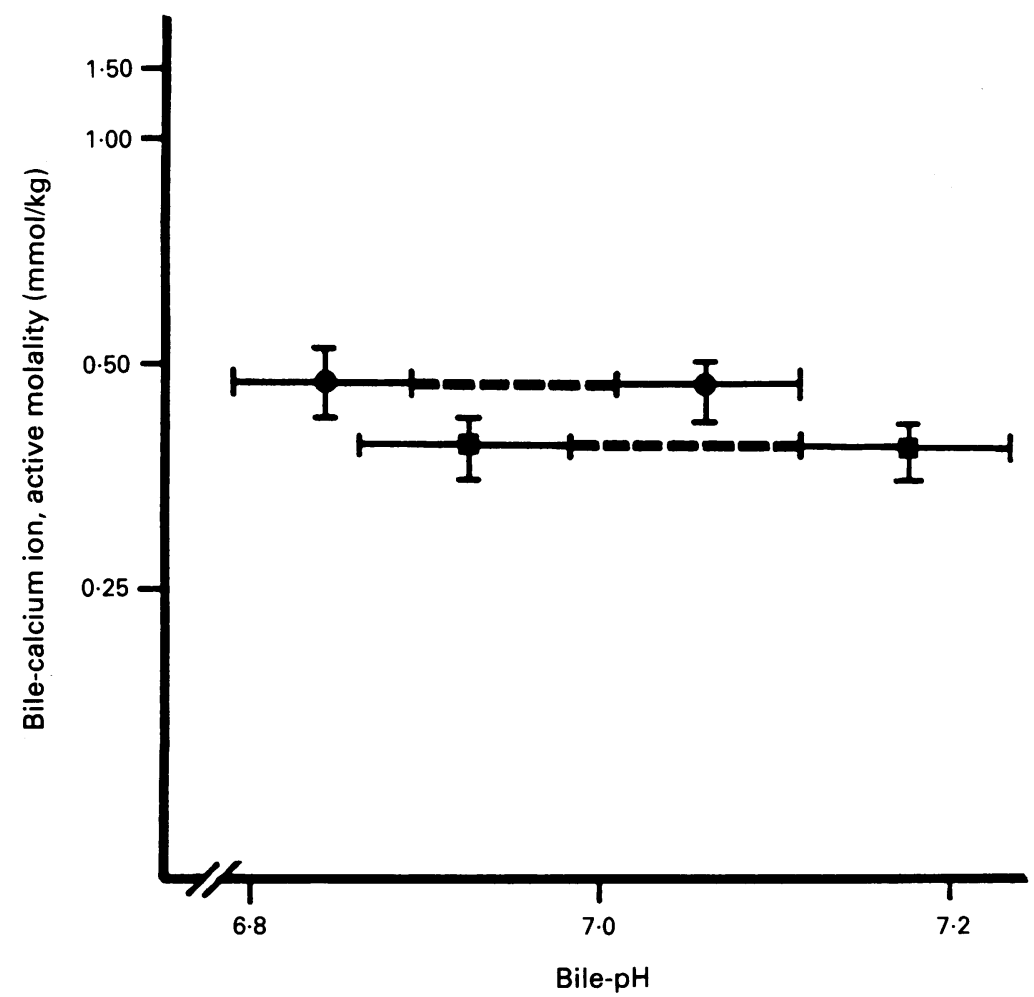

Figure 1: In vitro relation between the active molality of ionised calcium $\left(\mathrm{Ca}^{2+}\right)$ and $\mathrm{pH}$ at two different $\mathrm{CO}_{2}$ tensions $(5 \cdot 3 \mathrm{kPa}$ and $10 \cdot 6 \mathrm{kPa}$ ) in gall bladder bile from patients $(\mathrm{O})$ and controls ( $\mathbf{\square})$. The dashed lines denotes not continuous measurements. Median and $95 \%$ confidence limits are presented. approximately 25 measurements of the activity of $\mathrm{Ca}^{2+}$ and $\mathrm{pH}$.

Bile sodium $\left(\mathrm{Na}^{+}\right)$, potassium $\left(\mathrm{K}^{+}\right)$were measured potentiometric by a multichannel analyser (Technicon SMAC analyser, Tarrytown, USA), which also was used for measurements of albumin and bilirubin concentrations. Chloride $\left(\mathrm{Cl}^{-}\right)$was measured by colourmetric titration (CMT10, Radiometer, Copenhagen).

\section{LIQUID JUNCTION POTENTIAL $\left(\mathrm{E}_{\mathrm{j}}\right)$}

The liquid junction potential of the junction sodium formate $(4.6 \mathrm{~mol} / \mathrm{kg})$ and 'test solution' was calculated using the Henderson equation ${ }^{14}$ to be $-2 \cdot 1 \mathrm{mV}$ for the calibration solution and in gall bladder bile (Table) (containing 150, 7•0, 60, $30 \mathrm{mmol} / \mathrm{kg}$ ) for $\mathrm{Na}^{+}, \mathrm{K}^{+}, \mathrm{Cl}^{-}, \mathrm{HCO}_{3}{ }^{-}$) to be $-3.4 \mathrm{mV}$. The limiting molar conductance for cholic acid conjugated with either glycine or taurine is theoretically negligible considering the molar conductance of the other electrolytes. These results indicate that the residual liquid junction potential $\left(E_{j}\right)=E_{j}$ (gall bladder bile) $-E_{j}$ (calibr) is $-1.3 \mathrm{mV}$ corresponding to a bias on the measured $\mathrm{Ca}^{2+}$ activity of $-9 \cdot 5 \%$. The presented data for the activity of ionised calcium have not been corrected.

\section{STATISTICAL ANALYSIS}

The difference between median values were examined by Mann-Whitney test. Linear regression analysis was used to evaluate the relationship between the activity of $\mathrm{Ca}^{2+}$ and $\mathrm{pH}$. The relationship between the activity of $\mathrm{Ca}^{2+}$ and $\mathrm{pH}$ during titration studies included approximately 25 measurements of $\mathrm{Ca}^{2+}$ and $\mathrm{pH}$ in each bile sample. The best fit between these measurements for each patient was calculated by nonlinear regression analysis. The breaking points were defined without knowledge of the diagnosis. The statistical analysis were performed by Statistical Analysis System computer package 4.10 (SAS Institute Inc). A p value less than 0.05 was chosen as statistically significant.

\section{Results}

As shown in Table the activity of $\mathrm{Ca}^{2+}$ was significantly increased and $\mathrm{pH}$ significantly lower in gall stone patients compared with controls $(p<0.05)$, whereas no significant differences were observed as regards other electrolytes, albumin, or bilirubin.

\section{IN VITRO STUDIES}

$\mathrm{CO}_{2}$ equilibration

The slope $\Delta \operatorname{lg~} \mathrm{Ca}^{2+} / \Delta \mathrm{pH}$ measured by equilibrating whole gall bladder bile at two different $\mathrm{CO}_{2}$ tensions $(5.3 \mathrm{kPA}, 10.6 \mathrm{kPa})$ from gall stone patients $(n=10)$ and controls (nine) gave a mean value of -0.09 and -0.04 , respectively (NS) (Fig 1).

\section{Titration with $\mathrm{HCl}$ and $\mathrm{NaOH}$}

When the relationship between the $\mathrm{Ca}^{2+}$ activity 


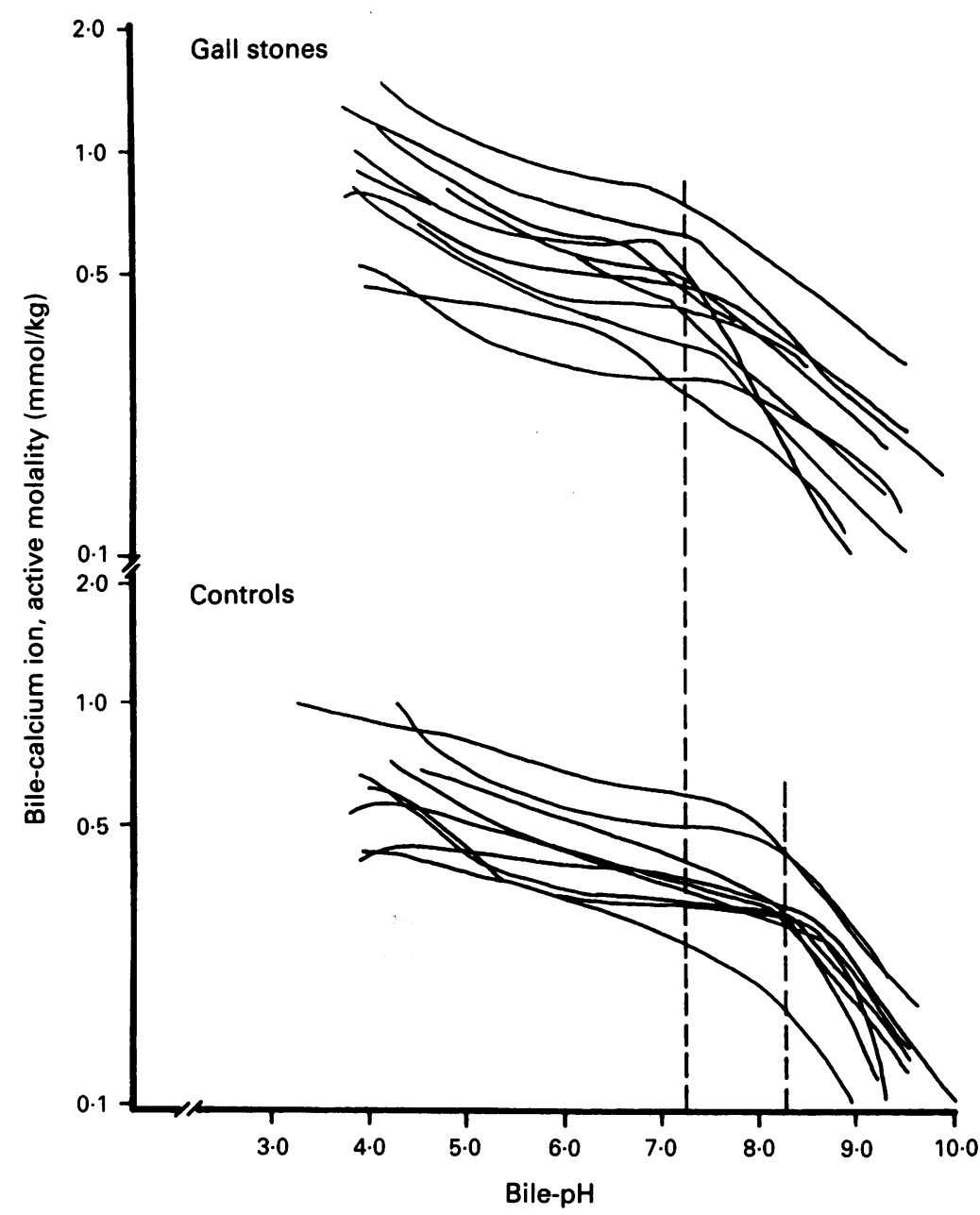

Figure 2: Active molality of ionised calcium $\left(\mathrm{Ca}^{2+}\right)$ (on a logarithmic scale) as a function of pH in humam bile titrated with $\mathrm{HCl}$ and $\mathrm{NaOH}$ from patients with gall stone disease and controls. The dotted lines denote the breaking points for gall stones $(p H 7 \cdot 1$, range $6 \cdot 1-7 \cdot 5)$ and without (pH $8 \cdot 2$, range $7 \cdot 9-8 \cdot 8$ ). (patients) who were not scheduled for biliary/ hepatic surgery. We did not find it feasible, however, because of potential ethical problems, to collect bile from such a patient group. We have, therefore, chosen a control group, which comprised patients with normal liver function tests and in whom the gall bladder was removed during liver resection. Furthermore, the levels of other biliary electrolytes did not differ among patients with gall stones and controls suggesting that contamination had not occurred.

We observed an inverse relationship between $\mathrm{Ca}^{2+}$ and $\mathrm{pH}$ whether the change in $\mathrm{Ca}^{2+}$ and $\mathrm{pH}$ was the result in variations of $\mathrm{CO}_{2}$ tensions or to added $\mathrm{HCl}$ or $\mathrm{NaOH}$. Therefore some of the higher activity of $\mathrm{Ca}^{2+}$ observed in gall bladder bile from patients with gall stone disease may be caused by the lower $\mathrm{pH}$. When we recalculated the activity of $\mathrm{Ca}^{2+}$ at the same $\mathrm{pH}(\mathrm{pH} \mathrm{7 \cdot 7)}$ using the formula for changes in $\mathrm{pCO}_{2},{ }^{15}$ however, the difference between the two groups was still apparent, indicating that the difference in $\mathrm{pH}$ may have only a minor influence on the observed difference in the $\mathrm{Ca}^{2+}$ activity when the $\mathrm{pH}$ changes are caused by variations in $\mathrm{pCO}_{2}$ (recalculating the actual activity in gall bladder bile from patients with gall stone disease and controls to a pH $7 \cdot 7$ gives an activity of 0.407 and $0.315 \mathrm{mmol} / \mathrm{kg}$, respectively) (Fig 1).

Previous authors have attempted to convert the measured ionised calcium activity to the substance concentration of free calcium. From a physicochemical point of view such a conversion seems inappropriate because the activities of the participating ions determine the solubility product for a given salt and hence the possibility for precipitation. Furthermore, calculation of the substance concentration as the activity divided by the activity coefficient is rather inaccurate. The activity coefficient of $\mathrm{Ca}^{2+}$ may vary considerably depending upon the ionic strength in gall bladder bile according to the Debye-Hückel equation. ${ }^{16}$ The activity coefficient in gall bladder bile may vary from 0.3 to 0.9 as estimated from measurements of the concentrations of sodium and potassium in pure bile salt solutions. ${ }^{2}$ Because of these difficulties artificial bile solutions have been prepared to a total ionic strength of $0.295 \mathrm{mmol} / \mathrm{l}$. From these artificial bile solutions formation constants and solution products for different calcium complexes have been calculated. ${ }^{2}$ If the previous data on substance concentration of free $\mathrm{Ca}^{2+}$ in gall bladder bile are converted back to active molality we find values in the same range as our values. ${ }^{8}$

The concentration of electrolytes in bile from patients with stones in the gall bladder did not differ significantly from controls. From our data the interference of the major cations in bile on the calcium electrodes may be considered very small (selective coefficients for $\mathrm{Na}^{+}, \mathrm{K}^{+}$about $10^{-1}$, and for $\left.\mathrm{Mg}^{2+} 10^{-3}\right) .{ }^{\text {is }}$ We have previously shown that hydrogen interference is negligible in the $\mathrm{pH}$ interval $5 \cdot 0$ to $9 \cdot 0 . .^{13}$

The small negative slope after in vitro $\mathrm{CO}_{2}$ equilibration of gall bladder bile $\left(\Delta \mathrm{lg} \mathrm{Ca}{ }^{2+} / \Delta\right.$ $\mathrm{pH}$ of -0.09 and -0.04$)$ is much lower than that found in human serum of $-0 \cdot 23$. In serum the changes in $\mathrm{Ca}^{2+}$ with the changes in $\mathrm{pH}$ are caused predominantly by the albumin concenhigher than what is normally reported in human gall bladder bile." Whether this may be because of some sort of 'contamination' of gall bladder bile with common duct bile ( $\mathrm{pH}$ in the range of $7 \cdot 5$ to 8.05 ) during liver examination can not be discounted. Theoretically this influence could have been eliminated by including controls 
tration, ${ }^{15}$ which explains the lower slope of $\Delta \mathrm{lg}$ $\mathrm{Ca}^{2+} / \Delta \mathrm{pH}$ in gall bladder bile (median albumin concentration $200 \mu \mathrm{mol} / 1$ compared with 650 $\mu \mathrm{mol} / 1$ in human serum). The theoretical calculated slope in gall bladder bile containing an albumin concentrations of $200 \mu \mathrm{mol} / 1$ gives a slope of -0.05 close to the observed value. Therefore, anaerobic sampling which is a necessity in serum because of the possible $\mathrm{CO}_{2}$ loss from the sample is not as crucial for the measurements of gall bladder bile because of the small effect on $\mathrm{Ca}^{2+}$ activity with a $\mathrm{CO}_{2}$ loss from the sample where $\mathrm{pH}$ changes only minimal. The titration studies, with a pH change of 4 to 10 units, however, showed that it is essential to measure the activity of $\mathrm{Ca}^{2+}$ and $\mathrm{pH}$ simultaneously because of the strong relationship between the $\mathrm{Ca}^{2+}$ activity and the $\mathrm{pH}$ of gall bladder bile. The increased activity of $\mathrm{Ca}^{2+}$ and the location of the breaking point at a significantly lower $\mathrm{pH}$ in patients with gall stone disease than in controls $(\mathrm{pH}=7 \cdot 1 v 8 \cdot 2)$ may increase the risk for precipitation of bile salts and may, as suggested by Moore, be a principal factor in the initiation of gall stone formation. ${ }^{217}$

In conclusion we find a higher activity of $\mathrm{Ca}^{2+}$ in gall bladder bile in patients with gall stone disease than in controls. Our results suggest that the activity of $\mathrm{Ca}^{2+}$ and $\mathrm{pH}$ may be important factors in the nucleation and ultimately the growth of gall stones. For the measurements of $\mathrm{Ca}^{2+}$ in gall bladder bile strictly anaerobic sampling is not crucial, as the activity of $\mathrm{Ca}^{2+}$ was not significantly affected by the small changes in $\mathrm{pH}$ caused by different $\mathrm{pCO}_{2}$ tensions. The close relationship between the $\mathrm{Ca}^{2+}$ activity and $\mathrm{pH}$ as a result of metabolic changes, however, may indicate the need to measure both parameters simultaneously in order to interpret data for the $\mathrm{Ca}^{2+}$ activity in gall bladder bile.

1 Sutor DJ, Wooley SE. A statistical survey of the composition of gallstones in eight countries. Gut 1971; 12: 55-64

2 Moore EW. The role of calcium in the pathogenesis of gall stones: $\mathrm{Ca}^{++}$electrode studies of model bile salt solution and other biologic systems. Hepatology 1984; 4: 228-43S.

3 Williamson BWA, Percy-Robb IW. Contribution of biliary lipids to calcium binding in bile. Gastroenterology 1980; 78: lipids to calc 702 .

4 Robertson WG, Marshall RW. Ionized calcium in body fluids. CRC Critical Reviews in Clinical Laboratory Sciences 1981; 15: 85-125.

5 Dawes LG, Nahrwold DL, Rege RV. Increased total and free onized calcium in a canine model of pigment gallstones. Surgery 1988; 104: 86-90.

6 Magnuson TH, Lillemoe KD, Peoples GE, Pitt HA. Ora calcium promotes pigment gallstone formation. I Surg Res 1989; 46: 286-91.

7 Rege RV, Moore EW. Pathogenesis of calcium-containing gallstones. 7 Clin Invest 1986; 77: $21-6$.

8 Strichartz SD, Abedin MZ, Abdou MS, Roslyn JJ. Increased biliary calcium in cholesterol gallstone formation. Am 7 Surg biliary calcium in

9 Sutor DJ, Wilkie LI, Jackson MJ. Ionised calcium in pathological human bile. $\mathcal{F}$ Clin Pathol 1980; 33: 86-8

10 Shiffman ML, Sugarman HJ, Kellum JM, Moore EW. Free calcium ion, $\left[\mathrm{Ca}^{2+}\right]$, is increased in gallbladder bile of patients with all types of gallstones [Abstract]. Hepatology 1989; 10: 601 .

11 Dawes LG, Rege RV. Calcium and calcium binding in human gallstones disease. Arch Surg 1990; 125: 1606-9.

12 Siggard-Andersen $\mathrm{O}$, Thode J, Fogh-Andersen N. What is ionized calcium? Scand $\mathcal{F}$ Clin Lab Invest 1983; 43 (suppl 165): 11-6.

13 Thode J. The calcium ion activity and the standardized excretion rate of calcium in urine of healthy adults. Scand $\mathcal{F}$ Clin Lab Invest 1985; 54: 327-34.

14 Siggaard-Andersen O, Fogh-Andersen N. The erytrocyte effect on the liquid junction potential: an osmotic dilution phenomenon. In: Maas AHJ, Buckley B, Manzoni A Moran RF, Siggaard-Andersen O, Sporkholt R, eds. IFCC Workshop. Stresa, Vol 10. 1988: 335-41.

15 Thode J, Wandrup J, Aas F, Siggaard-Andersen O. Evaluation of a new semiautomatic electrode system for simultaneous measurements of ionized calcium and $\mathrm{pH}$. Scand $\mathcal{F}$ Clin Lab Invest 1982; 42: 407-15.

16 Siggaard-Andersen $\mathrm{O}$, Thode J, Wandrup J. The concentration of free calcium ions in the blood plasma. Ionized calcium. Proceedings of the 5th meeting of the IFCC expert panel on pH and blood gases. Workshop. Copenhagen, June panel on $\mathrm{pH}$ and

17 Neithercut WD. Effects of calcium, magnesium and sodium ions on in vitro nucleation of human gall bladder bile. $G u t$ 1989; 30: 665-70. 